\title{
Employing DDR to Design and Develop a Flipped Classroom and Project based Learning Module to Applying Design Thinking in Design and Technology
}

\author{
Mohd Ridzuan Padzil, Aidah Abd Karim, Hazrati Husnin \\ Faculty of Education, Universiti Kebangsaan Malaysia \\ 43600 Bangi, Selangor, Malaysia
}

\begin{abstract}
The purpose of this study is to discuss the Design and Development (DDR) research approach that was used to develop a Flipped Classroom and project-based learning modules for students of Design and Technology (D\&T). The module's fundamental theory is based on 21st-century teaching and learning models, as well as design thinking. The DDR process is divided into three phases: analysis of needs, design and development, and evaluation. The phase of needs analysis is used to ascertain the necessity of module development and the application of design thinking. Three distinct data collection methods were used in this phase: semi-structured interviews, survey studies, and document analysis. The findings from this phase serve as a backup for the next phase. The Isman Instructional Design Model (2011) is adapted for use in this phase as a guide for module design and development. Additionally, the Fuzzy Delphi Method is used to obtain expert consensus on module material design, teaching and learning strategies, software development and hardware development requirements, and module prototype evaluation. The final phase is implementation and evaluation, which focuses on determining the module's effectiveness in the actual teaching and learning process. Each finding is organised and documented more systematically and orderly in accordance with the DDR phase in order to produce more meaningful research results. The conclusion of this article proposes a conceptual framework for the research.
\end{abstract}

Keywords-Flipped classroom; project-based learning; design and development (DDR); Isman instructional design model

\section{INTRODUCTION}

The establishment of quality students with a high level of skills and thinking ability to face the wave of global revolution of the 21st century can only be achieved by implementing a quality education system and in line with technological developments [1]. Thinking skill is a skill or ability of a person to use the intellect to understand, explore various ideas, make judgments, make decisions and solve problems [2]. These skills include analytical skills, synthesis skills, evaluative skills, and the ability to generate new and noble concepts to solve problems [3], [4]. In fact, mastery of a wide range of cognitive knowledge and skills, including problemsolving skills, reasoning and creative and innovative thinking, should be inculcated and instilled in each student's identity. These skills are needed to prepare students who are always ready to face increasingly complex, fast-paced, and highly challenging challenges now and in the future. Statistics show that $72.8 \%$ of the country's labor market for low-skilled and semi-skilled workers still depends on the skills of foreign workers. This is due to the existence of a 21 st-century skills gap among students regarding skills and knowledge. Trilling and Fadel [5] found that seven essential skills of the 21st century are poorly applied among students at secondary and tertiary levels, namely, oral and written communication, critical thinking, problem-solving skills, professionalism, teamwork, use of technology, leadership and project management.

The adaptation of design thinking skills becomes a part of the demand in the industrial and commercial areas. These fields need workers with problem-solving skills that can solve problems within multiple domains and can predict what the new issues will be [6], [7]. Design thinking began to emerge in the late 20, in which the idea was explored by developed countries, such as Singapore and Korea to face obstacles and difficulties of managing the economy. Another country, such as Denmark combined design thinking with a social science approach to create a novel solution for society [8]. Additionally, countries in the Asia Pacific region, such as China, South Korea and India promoted design thinking in university education through programs that concentrated on cultivating design thinking [6].

\section{A. STEM Education}

The demands of the 21 st-century industry in Industrial Revolution 4.0 are now more focused on students whose theoretical mastery and practical skills alone are no longer sufficient to thrive as workers in the 21st century [9], [10]. The UNESCO agenda, which places creativity and innovation as the key to sustainable development requires significant changes in economics, technology and society due to the emergence of a digital economy that encompasses innovation skills, creativity and inventors. needs to be handled efficiently [11]. Theoretical knowledge alone is not enough to make students competent and competitive. Students also need to have high skills, especially in practical or hands-on skills and skills in problem-solving, creative thinking, written and oral communication, and teamwork [10].

Education-based in Science, Technology, Engineering, and Mathematics, known as STEM is introduced and seen as a catalyzer for education transform to boost the quality of education in many countries. STEM education aims to build the workforce in the STEM domain and served as a critical 
vehicle for addressing the primary challenges of the 21st century [12]. The report of STEM Committee of the United States (US) National Council for Education, Science and Technology (2013) shows that to maintain American excellence in design and innovation, training and skills in STEM must be integrated in excellent working order. Even global companies in America promote the implementation of the STEM education system to ensure those job requirements in STEM are satisfied [13].

Design thinking skills and practices are quintessential ingredient in STEM education as it can benefit students' creativity and innovation in solving a problem. Such skills include analyzing the problems, creating and developing prototypes or models, gathering feedback, and redesigning creatively to solve the problems identified [14]-[16]. In other words, the advantage of one who practices design thinking proves that he or she is a competent individual and is always ready to meet the government's aim of developing human capital and the ability to become a globally competitive designer. Design thinking is also regarded as a particular skill that the students must master to match the needs of $21 \mathrm{st}-$ century student-centred learning in problem-solving [7].

\section{B. Design and Technology}

In Malaysia, design thinking starts to be deemed inevitable in the education system as a value-added to students to embrace challenges in the future. However, knowledge of theory is solely insufficient because other skills are pertinent to make the students competent, competitive, as well as creative and critical thinkers. Therefore, advancements in learning strategies, such as blended or hybrid learning, must intensify the students' competencies in the era of Industrial Revolution 4.0 [17].

Design and Technology (D\&T), also known as Reka Bentuk dan Teknologi (RBT) is a transformation in the education system in Malaysia from Secondary School Integrated Curriculum (KBSM) to Secondary School Standard Curriculum (KSSM). The course was offered in the high school syllabus in 2017 to provide students with creative thinking and the ability to integrate current technology in problem-solving.

Furthermore, the implementation of D\&T emphasises on how to design and produce quality products that are marketable [18]. Nevertheless, according to a report by Curriculum Development Division (BPK), the Ministry of Education Malaysia (MOE) addresses some issues and challenges that need to be overcome to enhance the quality and effectiveness of D\&T learning in schools [19] as shown in Table I.

The 21st-century teaching and learning strategies are an approach that can be used to enhance teachers' pedagogical skills and student competency. In this regard, teachers' pedagogical approaches should be diversified and related to the use of the latest technology. These approaches encompass planning activities, conducting research, analysing data, and communicating the information obtained [13]. Furthermore, this approach can help to address problems related to the time and teaching resources limitations faced by the D\&T teachers.
The flipped classroom is a teaching strategy in 21stcentury learning that uses blended learning methods based on online technology to improve students' knowledge and performance for engineering-related subjects, such as D\&T. Besides that, with the flipped classroom approach, problems related to time constraints, achievement, interest, knowledge, and students' motivation towards learning are resolved [20], [21]. Therefore, this approach is also suitable for D\&T subjects, especially the topic of the Design Process based on time constraints and others, as stated in the previous paragraph.

The main concept of flipped classroom approach according to Bergmann \& Sams [22] emphasizes six main features, namely: (i) shift teaching time; (ii) lectures can be accessed anywhere; (iii) active student involvement in the classroom; (iv) class workshops; (v) teachers as facilitators; and (vi) adapting learning using technology. These characteristics require teachers to think and apply new ideas that lead to learning objectives, learning processes and activities, assessment and future learning.

Project-based learning is one of the innovations introduced in the education system, which is an approach in the teaching and learning process that is student -centered. This learning approach encourages students to be active in the process of collaboration, communicating with each other in a small group to perform project assignments [23]-[27].

Project-based learning approach is an activity planned using problem -based learning (PBM) and inquiry learning approaches (BPK 2017). This method refers to activities that require students to identify methods to solve the problems presented and subsequently plan the entire project. Students take full responsibility for their project assignments, produce projects or artifacts as learning outcomes and present their assignments in front of peers and teachers for feedback.

TABLE I. D\&T ISSUES AND CHALLENGES

\begin{tabular}{|c|c|}
\hline Issues and Challenges & Description \\
\hline Student Readiness & $\begin{array}{l}\text { - Students are still weak in the development } \\
\text { and production of design ideas. } \\
\text { - Student readiness is low due to a lack of } \\
\text { exposure to basic practical practices such as } \\
\text { soldering, hammering, etc. } \\
\text { - Student readiness - Poor fundamental } \\
\text { knowledge displays a lack of basic } \\
\text { knowledge, for example, less skilled in } \\
\text { using hand tools. }\end{array}$ \\
\hline $\begin{array}{l}\text { Teaching and Learning } \\
\text { Resources (Teaching aids, } \\
\text { Module, Handbooks) }\end{array}$ & $\begin{array}{l}\text { - Lack of teaching and learning resources is } \\
\text { discovered. } \\
\text { - Training received during the course is not } \\
\text { sufficient } \\
\text { - Modules and handbooks should be available } \\
\text { for reference or trigger ideas for teachers. }\end{array}$ \\
\hline Teacher Readiness. & $\begin{array}{l}\text { - Teachers need specialized courses. } \\
\text { - A more detailed, more comprehensive guide } \\
\text { should be given. } \\
\text { - Teachers do not receive proper training and } \\
\text { exposure. }\end{array}$ \\
\hline
\end{tabular}


Project-based learning also can provide an active learning environment. A productive learning environment will be able to enhance students' knowledge through their experiences while engaging with learning activities and design project development in the classroom [2], [27]-[31]. Therefore, in this study, students' understanding of topics is crucial to determine the effect of applying design thinking skills on the development of students' knowledge through the implementation of flipped classroom module activities. Furthermore, even the integration of technology in projectbased learning in teaching and learning and the role of teachers as facilitators help the students develop their creative thinking to build the concepts learned using Internet technology as a medium of information delivery and obtaining various sources of learning materials.

\section{DESIGN AND DEVELOPMENT OF FLIPPED ClASSROOM AND PROJECT BASED LEARNING MODULE}

The conceptual framework is a description of the idea of the entire study conducted [32]. It is also a backbone of the research that aims to explain how an idea formed will drive the planning and implementation of a study. This module development is based on the Design and Development Research by Richey and Klein [33], which is a systematic technique used to develop teaching modules. It involves a process that includes needs analysis activities, determining what must be mastered, creating educational goals, material design to achieve objectives, and implementing and evaluating the teaching materials' effectiveness [33][34]. This approach contains three main systematic phases: the needs analysis, development design, and evaluation phase, as mentioned in Fig. 1.

\section{A. Phase 1- Need Analysis}

A needs analysis was the first phase in DDR. A needs analysis was a critical stage in developing a product, in which information could be obtained through customers directly or indirectly[35]-[37]. It was intended to look at the problems that arose to predict solutions to future customer needs. Environmental information among the selected population was collected and analysed to identify the matter's needs. This phase also focused on what should be doing compared to what had been done in a study that identified the need to develop flipped classroom and project-based learning modules on knowledge, skills and design thinking of D\&T students.

Discrepancy Model by McKillip [38] will used as a model of the needs analysis phase. The Discrepancy Model was a model used in the field of educational research. This model emphasised several expectations, namely the process of setting goals, the method of measuring performance that involved identifying what should be done and identifying discrepancy (discrepancy identification) that should have happened (what ought to be) and what exactly a problem was (what was). In the context of this study, needs analysis helped to obtain information about the need to develop flipped-classroom and project-based learning modules from the perspective of users, namely teachers and students based on the following research questions, namely, (i) Exploring the need for the application of design thinking for D\&T subjects based on the teacher's perspective; (ii) Exploring teachers views on the need for flipped classroom and project-based learning module to apply design thinking among D\&T students; and (iii) What is the level of readiness of the D\&T students towards the implementation of flipped classroom and project based learning module.

In this study, mixed data collection methods were employed in this needs analysis phase. The methods comprised semi-structured interviews, surveys and document analysis. This data collection method was used to obtain evidence or information from various sources to answer research questions [39]. The qualitative data collected provided an in-depth overview of the phenomena studied [42]. The overview consisted of requirements required in the process of design and development of modules. The interview method was an effective way to obtain information on opinions, thoughts, views, and experiences. The interview was also carried out to understand what was experienced and thought by the informants [43]. In addition, document analysis, such as data analysis on Sistem Pentaksiran Tingkatan Tiga (PT3) examinations for Form 3 students in 2019, Dokumen Standard Kurikulum dan Pentaksiran (DSKP) D\&T subjects and textbooks were also used to obtain justification and information to support the data collected. The survey method was chosen because it was a method of study that was planned following standard practices and exhibited a high level of trustworthiness. Apart from that, this method is sufficient to obtain views and needs about the issue stated and resolved [36]-[38]. The findings of this needs analysis justify that there is a need to develop teaching modules that focus on improving knowledge, skills and application of design thinking among lower secondary school students in D\&T subjects.

\section{B. Phase 2-Design and Development}

The second phase of design and development was an essential part of this research. Ven Den Akker, Gravemeijer, McKenney and Nievee [32] explained that this phase was crucial and should be emphasised because the developed products, whether modules, models, or curriculum, were relevant and needed to undergo detail to ensure it benefited the actual target audience.

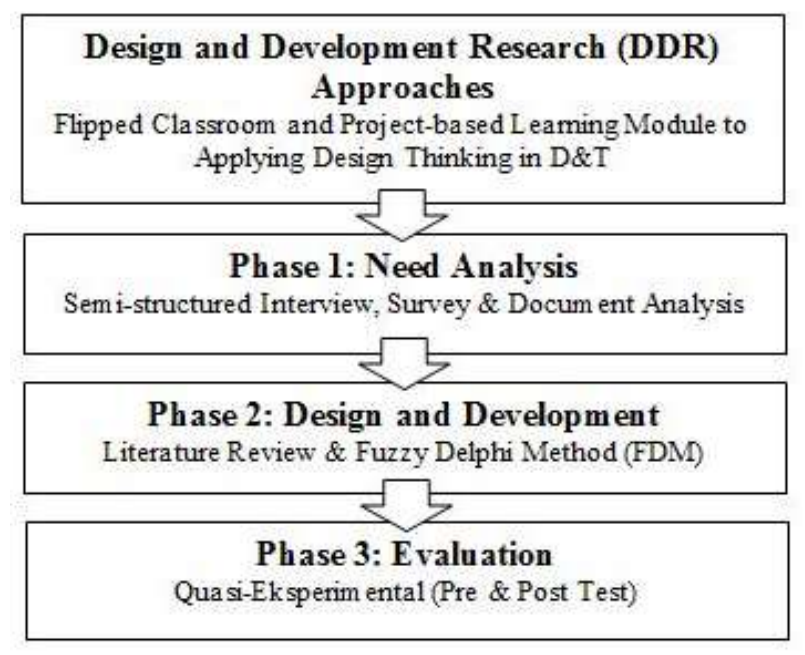

Fig. 1. Research Flow Chart. 
In this study, Isman instructional design model [40] and Gagne's Nine Events of Instruction [43] was employed to develop the module. This model contained several processes suitable for use in module development. Isman's model in Fig. 2 was an instructional design model that emphasised ways of planning, developing, implementing, evaluating, and organizing productive learning activities in ensuring student achievement [40]. The theoretical foundation of this study came from Behaviorism, Cognitivism and Constructivism views. The adaptation of this model was centred on the relationship between stimulus and student response to strengthen the students' knowledge of the environment in Behaviorism theory. Next, it was related to the mental learning process and the students' experience to enhance the students' motivation for a more effective learning process. As such, teaching activities in the model gave emphasis to the students on how to retain the knowledge gained over the long term.

The adaptation of these models in previous studies as a framework in the design and development of teaching modules had been proven through the successful development of teaching modules for Physics subjects [41] and graphic design learning modules for students with hearing problems [42]. Therefore, the selection of these models in this study was appropriate and in line with the primary objective of developing this module to improve the knowledge, skills and design thinking of students who took D\&T subjects. Table II illustrates the adaptation of the Isman instructional design model used in this study for the design and development phase. This relationship explained the need to implement to ensure that the project-based module development process used a flipped-classroom approach to student design thinking in the planned RBT subjects.

The first part of the design phase is the formation of key components and elements carried out through literature review and preliminary validation with several experts [43] to determine the list of components and elements involved in the design and development of module.

Learning theory and teaching models in designing and developing a teaching material must be given careful emphasis so that the modules produced will meet the learning objectives and can be implemented well. Such approaches and models are Constructivism Theory, Cognitive Theory with Multimedia Learning (Mayer 2009), Isman Teaching Model (Isman 2011), Gagne's 9 Step Teaching Model (1985), Reverse Classroom Model (Enfield \& State 2013), Project Based Learning (Katz \& Chad 2000) as well as the Design Thinking Model (Institute of Design. Stanford 2009) as in Table III.

To see to what extent components and elements are appropriate, components and elements will go through a content validation process [44]. The elements that have been formed are next through a content validation process that can see the extent to which the elements of design thinking that have been developed have been successfully defined. To obtain content validity, researchers have used an approach through expert evaluation as suggested by Creswell (2012) and Johnson and Christensen (2020) [45], [46].

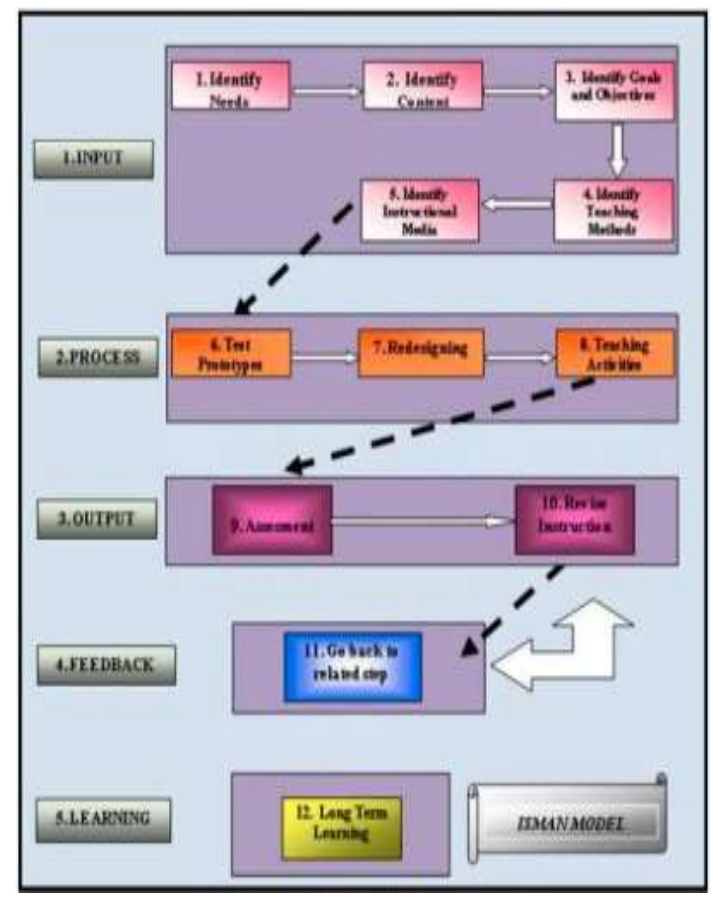

Fig. 2. Isman Instructional Design Model

TABLE II. ADAPTATION OF ISMAN INSTRUCTIONAL MODEL IN DESIGN AND DEVELOPMENT PHASE

\begin{tabular}{|c|c|c|}
\hline Step & Work Log & Description \\
\hline Input & $\begin{array}{l}\text { - Identify needs } \\
\text { - Identify content } \\
\text { - Identify learning objectives } \\
\text { - Identify teaching methods } \\
\text { - Identify assessment } \\
\text { materials } \\
\text { - Identify teaching media }\end{array}$ & $\begin{array}{l}\text { Design flipped classroom } \\
\text { and project-based learning } \\
\text { module to enhance } \\
\text { knowledge, skills, and } \\
\text { design thinking based on } \\
\text { expert opinion. } \\
\text { - Obtain expert agreement on } \\
\text { the design of the developed } \\
\text { module. }\end{array}$ \\
\hline Process & $\begin{array}{l}\text { - Prototype test } \\
\text { - Redesign instructions } \\
\text { - Teaching activities }\end{array}$ & $\begin{array}{l}\text { Development of module } \\
\text { prototype based on expert } \\
\text { consensus through Fuzzy } \\
\text { Delphi Method (FDM). }\end{array}$ \\
\hline Output & $\begin{array}{ll}\text { - Testing } \\
\text { - Result analysis }\end{array}$ & - Perform a pilot test \\
\hline Feedback & - Check instructions & $\begin{array}{l}\text { Review the comments } \\
\text { given by students and } \\
\text { teachers }\end{array}$ \\
\hline Learning & - Learning & $\begin{array}{l}\text { - Conduct the quasi- } \\
\text { experimental to evaluate } \\
\text { the effectiveness. }\end{array}$ \\
\hline
\end{tabular}

TABLE III. ADAPTATION OF TEACHING AND LEARNING MODEL IN DESIGN AND DEVELOPMENT PHASE

\begin{tabular}{|l|l|}
\hline Learning Theory & Model \\
\hline $\begin{array}{l}\text { Social Constructivism } \\
\text { Theory }\end{array}$ & Isman Instructional Design Model (Isman 2011) \\
\hline $\begin{array}{l}\text { Cognitive Theory } \\
\text { with Multimedia } \\
\begin{array}{l}\text { Learning (Mayer } \\
2009)\end{array}\end{array}$ & Gagne's 9 Events of Instruction (1985) \\
\cline { 2 - 2 } & Flipped Classroom Model (Enfield \& State 2013) \\
\hline & Project-based Learning Model (Katz \& Chad 2000). \\
\hline & Design Thinking Model (d. school Stanford 2009) \\
\hline
\end{tabular}


Therefore, a total of three field experts were selected consisting of design thinking experts, pedagogics and curriculum experts who acted to evaluate, examine the measurement of constructs, content or scale and then see how much a construct is relevant or related to the concept being measured [46]. Then, these already formed elements will be carried to the next phase.

Next, the Fuzzy Delphi Method (FDM) was used in the module development phase to obtain the agreement of a group of experts to confirm, evaluate, reject, and add each component and element received in the previous stage before developing the module prototype. The strength of this method involved the diversity of experts in determining and validating the components and elements selected in the development of the module, whether it was appropriate in the context of the study conducted.

This method was a method and instrument of measurement that improved the Delphi Technique that Murray, Pipino and Gigch introduced in 1985. Fuzzy Delphi Method or FDM was a combination of fuzzy set theory and the traditional Delphi method added by Kaufman and Gupota in 1998 [20], [47]. This improvement made FDM a measurement tool to be more productive and solve problems that had precision and uncertainty for a study [36]. This method was chosen because it was proven to obtain expert agreement to decide components and elements needed in the module development.

The selection of selected expert panels was based on the expertise and experience of the expert panel and focused on the areas studied. Berliner [36] stated that the selected specialist must have more than five years of consistent experience, and this would provide in-depth results related to the issues being studied. In this study, the panel of experts appointed comprised lecturers and teachers from various fields, such as Educational Technology, Curriculum, and D\&T.

Before that, a content validation process will be conducted to see the suitability of the components and elements was proposed [44]. To that end, researchers will use expert assessment as proposed by Creswell [45] and a total of three field experts consisting of design thinking experts, pedagogy and curriculum experts will be selected to evaluate, examine the construct measurements. Fig. 3 displays a flow chart using the Fuzzy Delphi (FDM) method to obtain empirical findings.

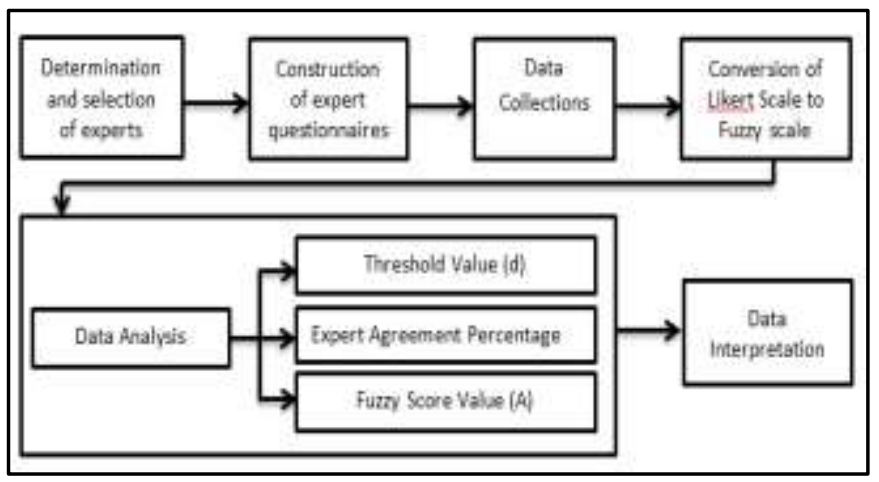

Fig. 3. Fuzzy Delphi Method (FDM) Approach.
In order to run the Delphi Fuzzy Method, several steps need to be followed to ensure that this study is considered an empirical study. There are:

Step 1: Formation of questions for the Fuzzy Delphi questionnaire was adaption from the previous research. In this step, the researchers have developed a questionnaire based on the literatur review and discussions with experts. The Likert scale of the questionnaire is based on the requirements of the research questions required to develop a flipped-classroom and project-based learning module to apply design thinking among RBT students. The developed questionnaires were submitted to the experts through two methods [37], namely, (i) meet face to face each expert and (ii) make online dissemination such as via email that has been identified as knowledgeable in the field studied.

Step 2: All linguistic variables are converted into fuzzy triangular numbers. The fuzzy rij number is a variable for each criterion representing the $\mathrm{K}$ expert.

$\mathrm{i}=1 \ldots \mathrm{m}, \mathrm{j}=1, \ldots \mathrm{n}, \mathrm{k}=1 \ldots, \mathrm{k}$ and $\mathrm{r}_{\mathrm{ij}}=1 / \mathrm{K}\left(\mathrm{r}^{1}{ } \pm \mathrm{r}^{2}{ }_{\mathrm{i}} \pm \mathrm{r}_{\mathrm{ij}}\right)$

Step 3: Data has been converted to a fuzzy scale using a Delphi Fuzzy Analysis template developed from Microsoft Excel software. The threshold value, (d), will be calculated based on the following formula:

$d(\tilde{m} \tilde{n})=\sqrt{\frac{1}{k}\left[\left(m_{1}-n_{1}\right)^{2}+\left(m_{2}-n_{2}\right)^{2}+\left(m_{3}-m_{3}\right)^{2}\right]}$

Step 4: According to Cheng and Lin [48], if the expert evaluation data is less than the threshold values of 0.2 , all experts consider that all experts have reached a consensus. Apart from that, if the group consensus percentage is more than $75 \%$, then the following data analysis is to use the Defuzzification Process to obtain the fuzzy score value (A). The value of the fuzzy score (A) must be greater than or equal to the median value ( $\alpha-$ cut value) of 0.5[49]. If the data findings are equal to or greater than 0.5 , this means that the item is accepted by expert agreement.

$A=(1 / 3) *(m 1+m 2+m 3)$

Through of the consensus experts obtained, prototypes of flipped-classroom and project-based module learning were developed. This phase involved restructuring the content program, organisation chart, storyboard, flowchart program, screen design, and evaluation process and repetition. Before the actual group thoroughly utilised module application, a pilot study on a group of students was conducted to identify problems that arose in the developed module.

\section{Phase 3-Evaluation}

The final phase in development design research is to evaluate the effectiveness of the module. Russell [48] stated that the evaluation of a developed module can be determined through activities or questions. There are three types of assessment that can be used to evaluate the entire module, namely, formative, summative and validation assessment [50] which is done during the teaching process, at the end of the teaching process and after the teaching and learning process. 
There are three main research questions in this phase, namely, (i) does the module help teachers apply design thinking from the aspect of teacher teaching and learning strategies?; (ii) does the module help to increase the knowledge of the Design Process among students?; (iii) does the module help to improve Design Process skills among students? and; (iv) Does the activities of the module help to inculcate design thinking among students? Evaluation focuses on through user evaluation of module activities implemented in actual teaching and learning process.

In this study, Quasi-experimental studies were used to determine the effect of pre-and post-test interventions between the two test groups. The implementation of this approach is done in the classroom i.e., real situations, to determine whether changes made in small group assessment can effectively be applied in real contexts [45]. To ensure that treatment had an effect on student performance, pre-tests were given to the two groups as a baseline and to show that both groups had similar cognitive development. Then a post-test will be given after treatment, and the difference between the pre-test and post-test scores will indicate whether there is a measurable effect after treatment. Fig. 4 shows the flow chart of the module effectiveness evaluation study procedure.

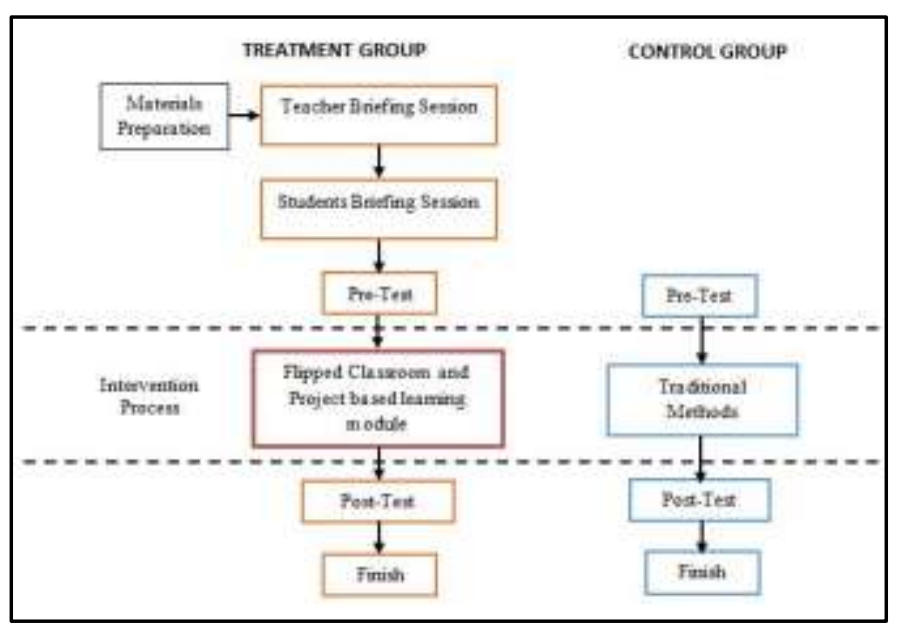

Fig. 4. Evaluation Phase Procedures.

The main difference between quasi-experimental and pure experimental studies is that the control and treatment student groups were not randomly selected due to several factors such as cost, time, logistics and evaluation of school administrators [47]. These differences cause the experimental study to be exposed to various threats or disruptions during the implementation process. Threat or interference of validity refers to interference that may threaten the study process being conducted and may cause the results obtained to possibly reflect false conditions of cause and effect between the treatment and control groups [45]. There are two types of experimental validity namely internal validity and also external validity.

Internal validity refers to the presence of differences on dependent variables as a result of manipulation of independent variables [47]. Internal effects need to be performed to ensure that the study findings are truly from the treatment of independent variables that are not influenced by any external variables.

External validity refers to the fact that the results of a study can be adopted by other groups with other environments and at different times as long as the characteristics of the study remain the same. It involves the results of the study findings can be generalized to other samples and study sites [47]. External threats refer to problems that interfere with researchers making correct inferences from sample data on others, past and future settings and situations [45].

The study sample in this phase is purposive sampling, that is, the study sample consists of two groups of students who take the subject of Design and Technology in a school. The minimum study sample of each group involved was a total of 35 students. Characteristics such as age, the number of students in the class, learning environment, study time and also teacher qualifications were determined in this study. Once the equivalent characteristics are set for both groups, random assignments were given to determine which class would act as the experimental group and the control group. The two selected groups had similar characteristics at the beginning of the quasi-experimental procedure, and this step was important to reduce bias (Kim \& Steiner, 2016) in the quasiexperimental procedure.

\section{RESEARCH CONCEPTUAL FRAMEWORK}

In designing and developing quality flipped classroom modules, various aspects needed to be a concern. The combination of several theories and learning models in the design and development study process had provided detailed and systematic guidelines according to several vital phases, namely Needs Analysis, Design and Development, and Evaluation. Fig. 5 shows this study's conceptual framework, which eventually formed a flipped classroom and projectbased learning module to enhance the students' knowledge, skills, and design thinking in RBT subjects. The basis of the flipped classroom approach was to expose and cultivate the students to be prepared with learning materials outside of study time before attending the class[21], [51], [52]. Thus, the students were ready with the fundamental knowledge through this approach and applied the knowledge gained in discussion sessions and group activities. 


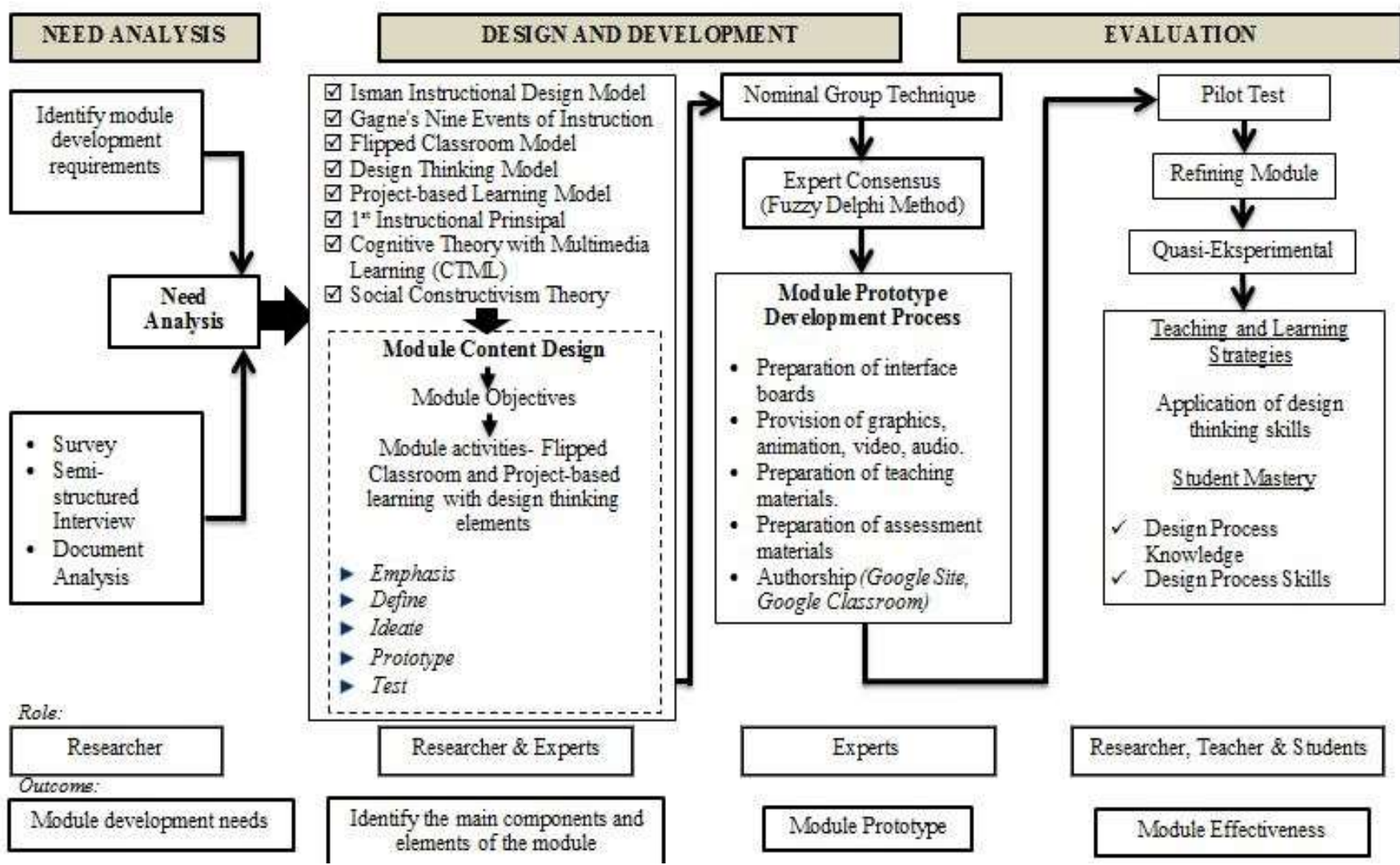

Fig. 5. Research Conceptual Framework (Adaptation Morisson II Model).

\section{CONCLUSION AND RECOMMENDATION}

Implementing the flipped classroom and project-based learning approach in the teaching process will help develop and cultivate the students' thinking and behaviour in a more positive and creative direction. Apart from that, the production of this module will make the classroom environment more active with the use of imaginative methods that actively involve the students in learning activities despite their different backgrounds. Moreover, through technological advances and implementing new policies in education, teachers are encouraged to redefine strategies and practical approaches in the teaching process. As a result, they are more competitive, as well as have creative and critical thinking.

This study is related to the process of design and development of flipped classroom and project-based learning module for the D\&T subjects. This adaptation involves three main phases in Design and Development Research (DDR): needs analysis, design and development, and evaluation. This developed module will present different insights from the existing flipped classroom approach. The application of design thinking and the emphasis on skills and knowledge of the design process will make the students better prepared to face the challenges of today's world. In conjunction with this awareness, it is hoped that this study will be able to contribute to the formation of future students to be more competitive and have creative and critical thinking.

\section{ACKNOWLEDGMENT}

We would like to thank all those who have supported and made this paper a success. Special thanks to the Ministry of Education Malaysia for the Hadiah Latihan Persekutuan (HLP) and University Kebangsaan Malaysia to carry out the study.

\section{REFERENCES}

[1] M. F. Mohd Rosdi, S. Abdul Kadir, and M. I. Nazri, "Tahap Kemahiran dan Kecenderungan Pemikiran Kritis Murid Tingkatan Dua Dalam Mata Pelajaran Kemahiran Hidup Bersepadu (KHB) di Negeri Kedah dan Hubungannya," Asia Pacific J. Educ. Educ., vol. 32, pp. 45-60, 2018.

[2] K. A. Kadir, N. M. Nordin, and Z. Iksan, "Reka Bentuk dan Pembangunan Modul Sains (e-SMART) Berasaskan Pendekatan Konstruktivisme 5E dan Analogi: Satu Alternatif Strategi Pengajaran Bagi Menerapkan Kemahiran Berfikir Kreatif Murid," vol. 1, p. 80, 2017

[3] S. Z. Salleh and A. S. Shaari, "Pelaksanaaan Kemahiran Berfikir, Sikap Pelajar dan Masalah Untuk Mengaplikasikan Kemahiran Berfikir dalam Pengajarandan Pembelajaran Bahasa Melayu," vol. 9, no. November, pp. $1-10,2019$.

[4] R. E. Mayer, "2003_Cognitive Theory of Multimedia Learning," Educational Psychologist, vol. 38, no. 1. pp. 43-52, 2003.

[5] B. Triling and C. Fadel, "Century Skills," 21St Century Ski., no. Book, p. $48,2009$.

[6] Toshiaki Kurokawa, "Design Thinking Education at Universities and Graduate Schools," Sci. Technol. Trends, vol. 46, pp. 50-63, 2013.

[7] K. L. Cook and S. B. Bush, "Design thinking in integrated STEAM learning: Surveying the landscape and exploring exemplars in elementary grades," Sch. Sci. Math., vol. 118, no. 3-4, pp. 93-103, 2018 
[8] K. K. Hewitt, W. Journell, and R. Zilonka, "What the flip: impact of flipped instruction on self-regulated learning," Int. J. Soc. Media Interact. Learn. Environ., vol. 2, no. 4, p. 303, 2014.

[9] S. Ismail, "Kesediaan guru terhadap pelaksanaan mata pelajaran Reka Bentuk dan Teknologi (RBT) sekolah rendah di Malaysia," Universiti Tun Hussein Onn Malaysia, 2012.

[10] M. Lynch, U. Kamovich, K. K. Longva, and M. Steinert, "Combining technology and entrepreneurial education through design thinking: Students' reflections on the learning process," Technol. Forecast. Soc. Change, no. June, p. 119689, 2019.

[11] A. Athanassios and B. Vasiliki, "education sciences Developing and Piloting a Pedagogy for Teaching Innovation, Collaboration , and CoCreation in Secondary Education Based on Design Thinking," Educ. Sci., no. i, pp. 1-11, 2019.

[12] R. W. Bybee, "What is STEM education?," Science (80-. )., vol. 329, no. 5995, p. 996, 2010.

[13] C. Yata, T. Ohtani, and M. Isobe, "Conceptual framework of STEM based on Japanese subject principles," Int. J. STEM Educ., vol. 7, no. 1, 2020.

[14] Y. Li et al., "Design and Design Thinking in STEM Education," J. STEM Educ. Res., vol. 2, no. 2, pp. 93-104, 2019.

[15] R. Razzouk and V. Shute, "What Is Design Thinking and Why Is It Important?," Rev. Educ. Res., vol. 82, no. 3, pp. 330-348, 2012.

[16] B. Hokanson, A. Gibbons, D. Thinking, and D. Process, Design in Educational Technology. 2014.

[17] Rusli, A. Rahman, A. S. Ahmar, and Hastuty, "The design of digital teaching material of higher education in industrial revolution 4.0," J. Crit. Rev., vol. 7, no. 1, pp. 298-299, 2020.

[18] M. Malaysia Education Blueprint, "Malaysia Education Blueprint 2013 2025," Education, vol. 27, no. 1, pp. 1-268, 2013.

[19] K. Unit Penyelidikan dan Pentaksiran Sekolah, "Kajian Tahap Pelaksanaan Kurikulum Standard Sekolah Menengah (KSSM)," 2019.

[20] Zanariah Ahmad, "Pembangunan Modul Pedagogi Kelas Berbalik Berasaskan Pembelajaran Reflektif Untuk Politeknik Premier," 2017.

[21] M. Alias, Z. H. Iksan, A. A. Karim, A. M. H. M. Nawawi, and S. R. M. Nawawi, "A Novel Approach in Problem-Solving Skills Using Flipped Classroom Technique," Creat. Educ., vol. 11, no. 01, pp. 38-53, 2020.

[22] G. S. Mason et al., Flipped Classroom As Innovative Practice in the Higher Education System: Awareness and Attitude, vol. 3, no. SGEM2016 Conference Proceedings, ISBN 978-619-7105-72-8 / ISSN 2367-5659. 2012.

[23] J. D. Badia and V. M. Soria, Creative Project-based learning to boost technology innovation, vol. 29, no. 2. Springer Netherlands, 2019.

[24] S. H. Halili and S. A. Ramas, "Penerimaan Guru Sekolah Rendah Terhadap Pendekatan Kelas Berbalik Dalam Mata Pelajaran Bahasa Tamil," no. April, pp. 10-17, 2019.

[25] K. Missildine, R. Fountain, L. Summers, and K. Gosselin, "Flipping the classroom to improve student performance and satisfaction," J. Nurs. Educ., vol. 52, no. 10, pp. 597-599, 2013.

[26] S. J. DeLozier and M. G. Rhodes, "Flipped Classrooms: a Review of Key Ideas and Recommendations for Practice," Educational Psychology Review. 2017.

[27] A. S. Shaarani and N. Bakar, "A New Flipped Learning Engagement Model to Teach Programming Course," vol. 12, no. 9, pp. 57-65, 2021.

[28] N. Isa, M. Machmudi, M. A. I. Shihah, and H. J. Abdullah, "Pembelajaran Berasaskan Projek: Takrifan , Teori dan Perbandingannya dengan Pembelajaran Berasaskan Masalah," CREAM -Current Researc in Malaysia, vol. 2, no. 1, pp. 181-194, 2013.

[29] J. M. Allison, "Project Based Learning to Promote 21st Century Skills : An Action Research Study (Doctoral Dissertation)," no. May, 2018.
[30] A. Nordin, S. N. Salleh, and J. H. Abdullah, "Inovasi Pembelajaran Berasaskan WBL dan Triple Helix dalam Pembelajaran di Politeknik," vol. 3, pp. 111-120, 2018.

[31] A. Aziz Hussin, T. Sarifah Aini Syed Ahmad Akademi Pengajian Bahasa, U. Teknologi MARA, and S. Alam, "Designing a Flipped Classroom Lesson Using the AOCAR Technique," no. October, 2019.

[32] J. Van den Akker, "Educational Design Research," Educ. Des. Res., 2006.

[33] R. C. Richey and J. D. Klein, "Developmental research methods: Creating knowledge from instructional design and development practice," J. Comput. High. Educ., vol. 16, no. 2, pp. 23-38, 2005.

[34] R. C. Richey, J. D. Klein, and W. a Nelson, "Developmental research: Studies of instructional deisgn and development," Handb. Res. Educ. Commun. Technol., pp. 1099-1130, 2004.

[35] S. Siraj, N. Alias, D. DeWitt, H. Zaharah, and M. J. Mohd Ridhuan, Design and Development Research: Emergent Trends in Educational Research. 2013.

[36] M. J. Mohd Ridhuan, "Pembangunan Model Kurikulum Latihan SkiVes Bagi Program Pengajian KejuruteraanPembelajaran Berasaskan Kerja," 2016.

[37] A. Abdul Muqsith, "Pembangunan Model Eni Berasaskan Aktiviti Inkuiri Bagi Program Latihan Kemahiran,” 2018.

[38] Ramlan Mustapha, "Reka Bentuk Model Integriti Akademik Berasaskan Penghayatan Rohani," vol. ى, no. ى, p. ى, 2017.

[39] J. Creswell and V. Plano Clark, Designing and Conducting Mixed Methods Research. Sage Publication, 2007.

[40] A. Işman, "Instructional design in education: New model," Turkish Online J. Educ. Technol., vol. 10, no. 1, pp. 136-142, 2011.

[41] N. Alias and S. Siraj, "Effectiveness of Isman Instructional Design Model in Developing Physics Module based on Learning Style and Appropriate Technology," Procedia - Soc. Behav. Sci., vol. 64, pp. 12 17, 2012.

[42] Ibrahim Zainuddin, "Pembangunan Modul Pembelajaran Seni Reka," p. 429, 2017.

[43] C. Okoli and S. D. Pawlowski, "The Delphi method as a research tool: An example, design considerations and applications," Inf. Manag., vol. 42, no. 1, pp. 15-29, 2004

[44] U. Sekaran and R. Bougie, Research Methods for Business. 2014.

[45] J. Creswell, Educatyional Research: Planning, Conducting and Evaluating Quantitative and Qualitative Research - 4th ed, 4th ed. Pearson, 2013.

[46] R. B. Johnson and L. Christensen, Educational Research Quantitative, Qualitative, and Mixed Approaches Seventh Edition. 2020.

[47] N. M. Noh, S. Siraj, S. H. Halili, M. R. M. Jamil, and Z. Husin, "Application of fuzzy delphi method as a vital element in technology as a tool in design thinking based learning," Asia Pacific J. Educ. Educ., vol. 34, no. d, pp. 129-151, 2019.

[48] C. Cheng and Y. Lin, "Evaluating the best main battle tank using fuzzy decision theory with linguistic criteria evaluation," vol. 142, pp. 174$186,2002$.

[49] J. Cheng and C. Tang, "An Application of Fuzzy Delphi and Fuzzy AHP for Multi-criteria Evaluation on Bicycle Industry Supply Chains," vol. 4, no. 1, pp. 21-34, 2009.

[50] R. C. Richey and J. D. Klein, Design and Development Research Methods, Strategies, and Issues. 2007.

[51] J. Enfield, "Looking at the Impact of the Flipped Classroom Model of Instruction on Undergraduate Multimedia Students at CSUN," TechTrends, vol. 57, no. 6, pp. 14-27, 2013.

[52] A. A. Rahman, N. M. Zaid, Z. Abdullah, H. Mohamed, and B. Aris, "Emerging project based learning in flipped classroom: Technology used to increase students' engagement," 2015 3rd Int. Conf. Inf. Commun. Technol. ICoICT 2015, no. July, pp. 212-215, 2015. 